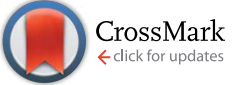

Cite this: RSC Adv., 2017, 7, 10729

Received 21st November 2016 Accepted 14th January 2017

DOI: 10.1039/c6ra27104a

rsc.li/rsc-advances

\section{Effect of metal on the methanol to aromatics conversion over modified ZSM-5 in the presence of carbon dioxide}

\author{
Caixia Xu, Binbo Jiang, ${ }^{*}$ Zuwei Liao, Jingdai Wang, Zhengliang Huang \\ and Yongrong Yang
}

\begin{abstract}
To improve the aromatics yield of methanol to aromatics conversion (MTA) over zeolite, which has become a potential route for producing aromatics, modified ZSM- 5 catalysts with equimolar metals denoted as EM$\mathrm{X} / \mathrm{ZSM}-5$ ( $\mathrm{X}=\mathrm{Zn}, \mathrm{Cu}, \mathrm{Ag}$, and $\mathrm{Ni}$ ) were investigated under $\mathrm{CO}_{2}$ and $\mathrm{N}_{2}$ flow for MTA in a fixed-bed reactor. The physicochemical properties were characterized by atomic absorption spectroscopy (AAS), $\mathrm{N}_{2}$ adsorption-desorption isotherms, X-ray diffraction (XRD), and $\mathrm{NH}_{3}$ temperature-programmed desorption ( $\left.\mathrm{NH}_{3}-\mathrm{TPD}\right)$. Comparison with the results obtained in pure $\mathrm{N}_{2}$ flow showed that catalysts doped with $\mathrm{Zn}, \mathrm{Ni}$, and $\mathrm{Ag}$ could promote aromatization activity and BTX yield in the presence of $\mathrm{CO}_{2}$. Among these, EM-Zn/ZSM-5 showed an aromatics yield of $59.05 \%$, with an increase of $8.1 \%$, whereas EM-Cu/ZSM-5 was found to reduce the aromatization activity in the presence of $\mathrm{CO}_{2}$. Moreover, the interaction mechanism of the active sites of the catalysts with $\mathrm{CO}_{2}$ for the MTA reaction was explored on the basis of the absorbability of the catalysts for $\mathrm{CO}_{2}$, which was studied by $\mathrm{CO}_{2}$ temperatureprogrammed desorption ( $\left.\mathrm{CO}_{2}-\mathrm{TPD}\right)$; the activation ability for $\mathrm{CO}_{2}$ to combine with hydrogen was investigated by the catalytic reaction of $\mathrm{CO}_{2}+\mathrm{H}_{2}$, and the verification experiments for the coupling behavior of ZSM-5 doped with different contents of $\mathrm{Zn}$ in the presence of $\mathrm{CO}_{2}$ were carried out.
\end{abstract}

\section{Introduction}

In recent years, the demand for light aromatics, such as BTX (benzene, toluene, and xylene), has sharply increased and the growth rate over the next five years is expected to be about 3.5$4.0 \%$ per year. ${ }^{1,2}$ However, aromatic production based on petrochemical processes has reduced owing to the decrease of catalytic reforming capacity, the increase of diesel demand, and the tendency towards light raw materials. ${ }^{3}$ Moreover, syngas-derived methanol production has become a serious issue with the rapid development of the coal chemical industry. Thus, the conversion of methanol to aromatics (MTA) is considered as a potential way that can not only alleviate surplus of methanol and deficiency of aromatics but also optimize the energy structure. ${ }^{4}$

The low-aromatic yield and BTX selectivity are the main limiting factors of MTA that hinder the industrial application of MTA. Methanol forms aromatics via complicated reactions, including dehydration, oligomerization, and hydrogen transfer reaction, on the acid sites of zeolite and produces a considerable amount of alkanes that take up carbon atoms and reduces the aromatics yield. ${ }^{5}$ Salts of dehydro-metals, such as $\mathrm{Ga}, \mathrm{Cu}$, $\mathrm{Zn}$, and $\mathrm{Ag}$, have been used to modify ZSM-5 catalysts to

State Key Laboratory of Chemical Engineering, College of Chemical and Biological Engineering, Zhejiang University, Hangzhou 310027, P. R. China. E-mail: jiangbb@ zju.edu.cn; Tel: +86-13819195891 improve the aromatics yield of MTA. ${ }^{6-10}$ The aromatics yield improved due to the fact that dehydro-metals on the ZSM-5 catalysts can speed up the hydrogen transfer of olefins and reduce the content of alkanes by replacing olefins as temporal hydrogen anion receptors. ${ }^{11}$ However, dehydrogenation and hydrogenation over dehydro-metals is a dynamic balance process, such that hydrogen produced by dehydrogenation cannot be eliminated in situ. Consequently, a large proportion of olefins will be combined with hydrogen to generate alkanes again. ${ }^{\mathbf{1 2}}$ Therefore, if appropriate receptors of hydrogen are provided to cut off the hydrogenation of olefin intermediates into alkane byproducts, the aromatic yield of MTA could be greatly increased.

Oxidizing gases, such as $\mathrm{O}_{2}, \mathrm{~N}_{2} \mathrm{O}, \mathrm{SO}_{2}$, and $\mathrm{CO}_{2}$, can be utilized as hydrogen receptors. ${ }^{13-15}$ Among these, the utilization of $\mathrm{CO}_{2}$, which is a main contributor to the global warming effect, to form functional $\mathrm{CO}$ is very meaningful and interesting. ${ }^{16}$ It was found that carbon dioxide could significantly enhance the dehydrogenation via eliminating hydrogen produced in situ by a reverse water-gas-shift reaction in the dehydrogenation of isobutane to isobutene on $\mathrm{VMgO}_{x} \cdot{ }^{17}$ The good performance of carbon dioxide has also been reported in other studies. ${ }^{18,19}$ Junhui Li et al. ${ }^{20}$ investigated the MTA reaction over NiO-ZSM-5 under $\mathrm{CO}_{2}$ atmosphere and claimed that $\mathrm{CO}_{2}$ activated by $\mathrm{NiO}$ species could accelerate the dehydrogenation in the conversion of olefin intermediates to aromatics by 
reacting with $\mathrm{H}_{2}$, produced in the MTA reaction, and could then promote aromatization. However, as is well-known, different metals loaded onto the catalyst have different dehydrogenation abilities for the aromatization reaction ${ }^{7,8,10}$ and different $\mathrm{CO}_{2}$ activation abilities for accepting the removed hydrogen; ${ }^{21}$ however, and their roles in MTA are still not clear. Therefore, the match of the loaded catalyst with $\mathrm{CO}_{2}$ and the interaction mechanism for the MTA reaction require further investigation, which could contribute a method for further improving the yield of aromatics.

Herein, we report a comparative study of the influence of $\mathrm{CO}_{2}$ on the performance of methanol aromatization over ZSM-5 catalysts doped by $\mathrm{Zn}, \mathrm{Ni}, \mathrm{Ag}$, and $\mathrm{Cu}$. Particularly, we mainly focused on clarifying the interaction mechanism of the active sites of the modified catalysts with $\mathrm{CO}_{2}$ for the MTA reaction on the basis of the characterization of the physicochemical properties of the prepared catalysts, the catalytic performance of the coupling of $\mathrm{CO}_{2}$ with $\mathrm{H}_{2}$, and the methanol aromatization over the catalysts modified with different contents of $\mathrm{Zn}$ in the presence or absence of $\mathrm{CO}_{2}$.

\section{Experimental}

\subsection{Catalyst preparation}

All ZSM-5 catalysts doped with metals were prepared using the excessive impregnation method, and all impregnating solutions had $5 \%$ excess compared with the method of incipient wetness impregnation. ZSM-5 zeolite $\left(\mathrm{SiO}_{2} / \mathrm{Al}_{2} \mathrm{O}_{3}=38\right)$ was pressed, crushed, and sorted to obtain particles of 14-20 mesh, and then dried in an oven at $150{ }^{\circ} \mathrm{C}$ for $6 \mathrm{~h}$. The metal-doped ZSM-5 catalyst was obtained by the impregnation of dried ZSM-5 zeolite particles with the nitrate solutions of precursors at room temperature for $15 \mathrm{~h}$ and calcination at $500{ }^{\circ} \mathrm{C}$ for $3 \mathrm{~h}$ after drying for $3 \mathrm{~h}$ at $105{ }^{\circ} \mathrm{C}$. ZSM-5 zeolite was purchased from the Catalyst Plant of Nankai University. The metal precursors used were $\mathrm{AgNO}_{3}, \mathrm{Ni}\left(\mathrm{NO}_{3}\right)_{2} \cdot 6 \mathrm{H}_{2} \mathrm{O}, \mathrm{Zn}\left(\mathrm{NO}_{3}\right)_{2} \cdot 6 \mathrm{H}_{2} \mathrm{O}$, and $\mathrm{Cu}\left(\mathrm{NO}_{3}\right)_{2}$ $\cdot 3 \mathrm{H}_{2} \mathrm{O}$ and were purchased from Sinopharm Chemical Reagent Co., Ltd. The modified ZSM-5 with equimolar $\left(0.229 \mathrm{mmol} \mathrm{g}^{-1}\right)$ $\mathrm{X}(\mathrm{X}=\mathrm{Zn}, \mathrm{Cu}, \mathrm{Ag}$, and Ni) metal was denoted as EM-X/ZSM-5. The ZSM-5 loaded with different $\mathrm{Zn}$ contents was denoted as $n \mathrm{Zn} / \mathrm{ZSM}-5$ (where $n$ denotes the $\mathrm{Zn}$ content). Note that $0.229 \mathrm{mmol} \mathrm{g}^{-1}$ of $\mathrm{Zn}$ is about $1.5 \mathrm{wt} \%$ of $\mathrm{Zn}$.

\subsection{Catalyst characterization}

The actual amount of metal elements in ZSM-5 zeolites was determined by atomic absorption spectroscopy (AAS, Z-2000). The samples were pretreated as follows: hydrofluoric acid was added dropwise to $100 \mathrm{mg}$ catalyst powder until framework traces remained. Then, the samples were completely dissolved by concentrated nitric acid and finally diluted using deionized water.

$\mathrm{N}_{2}$ adsorption-desorption experiments were performed using a physical adsorption instrument (Micromeritics, ASAP2020). The specific surface area and pore volume were calculated by the BET method and $t$-plot method, respectively. The crystal structure of the catalysts was characterized via X-ray diffraction analysis (XRD, X'Pert PRO X/PANalytical) using Cu
$\mathrm{K} \alpha$ radiation at a scan rate of $1^{\circ} \mathrm{min}^{-1}$ in the $2 \theta$ range from 5 to $50^{\circ} . \mathrm{NH}_{3}$-TPD and $\mathrm{CO}_{2}$-TPD experiments were performed using a physical and chemical adsorption instrument (Quantachrome, ASiQ). The samples (150 mg) were outgassed and dried at $470{ }^{\circ} \mathrm{C}$ for $1 \mathrm{~h}$ under He flow $\left(45 \mathrm{~mL} \mathrm{~min}^{-1}\right)$, cooled down to $120{ }^{\circ} \mathrm{C}\left(\mathrm{NH}_{3}\right.$-TPD) or $100{ }^{\circ} \mathrm{C}\left(\mathrm{CO}_{2}\right.$-TPD), treated with $\mathrm{NH}_{3}$ or $\mathrm{CO}_{2}$ (10 wt\% $\mathrm{NH}_{3}$ or $\mathrm{CO}_{2}$, He in balance) at $35 \mathrm{~mL} \mathrm{~min}^{-1}$ for $1 \mathrm{~h}$, and then purged with $\mathrm{He}$ at the adsorption temperature for $1 \mathrm{~h}$. The samples were then linearly heated at $10{ }^{\circ} \mathrm{C} \min ^{-1}$ to $600{ }^{\circ} \mathrm{C}$ $\left(\mathrm{NH}_{3}\right.$-TPD) or $500^{\circ} \mathrm{C}\left(\mathrm{CO}_{2}\right.$-TPD) in $45 \mathrm{~mL} \mathrm{~min}{ }^{-1} \mathrm{He} . \mathrm{NH}_{3}$ or $\mathrm{CO}_{2}$ released during the heating for desorption was measured by a thermal conductivity detector (TCD).

\subsection{Catalyst testing}

Catalytic reactions were carried out at ambient pressure using a down-flow stainless fixed-bed reactor with an internal diameter of $13 \mathrm{~mm}$. The prepared catalyst $(2.4 \mathrm{~g})$ was packed in a constant temperature zone and pretreated in $\mathrm{N}_{2}$ at $500{ }^{\circ} \mathrm{C}$ for $1.5 \mathrm{~h}$. Reactions were carried out at $1.0 \mathrm{~h}^{-1} \mathrm{WHSV}$ of methanol and atmospheric pressure in $30.8 \mathrm{~mL} \mathrm{~min}^{-1} \mathrm{~N}_{2}$ flow or the mixture of $\mathrm{N}_{2}$ and $\mathrm{CO}_{2}$ after reducing the temperature to $475^{\circ} \mathrm{C}$. $\mathrm{C}_{1}-\mathrm{C}_{6+}$ aliphatics were analyzed using a gas chromatograph (Agilent, GC7820A) equipped with a FID detector and a $50 \mathrm{~m} \mathrm{HP}$ PLOT-Q capillary column. Benzene- $\mathrm{C}_{10+}$ was analyzed using a gas chromatograph (Agilent, GC7820A) equipped with an FID detector and a $50 \mathrm{~m} \mathrm{HT}-1301$ capillary column. $\mathrm{H}_{2}, \mathrm{CO}$, and $\mathrm{CO}_{2}$ in tail gas were analyzed using a gas chromatograph (Agilent, GC7820A) equipped with a TCD detector and a $30 \mathrm{~m}$ GDX-502 molecular column (carrier gas, Ar). The yield of aromatics and BTX was calculated as follows:

Yield of aromatics/BTX $\%$

$$
=100 \times \frac{\text { aromatics } / \mathrm{BTX}-\text { weight in products } / \mathrm{h}}{\text { methanol in feed } / \mathrm{h} \times 0.4375}
$$

\section{Results and discussion}

\subsection{Methanol aromatization over the catalysts modified with different metals in the presence or absence of $\mathrm{CO}_{2}$}

The aromatic yield and BTX yield in the MTA reaction over the catalysts-loaded different equimolar metal components in the presence and absence of $\mathrm{CO}_{2}$ are shown in Fig. 1. The detailed product distributions of the MTA reaction for the abovementioned examples are listed in Table 1. Herein, it was observed that the conversion of methanol on all the catalysts was $100 \%$ under the test conditions.

In the pure $\mathrm{N}_{2}$ atmosphere, the yields of aromatics over ZSM5 doped with $\mathrm{Zn}, \mathrm{Cu}$, and $\mathrm{Ag}$ were enhanced to $50.9 \mathrm{wt} \%, 39.1$ $\mathrm{wt} \%$, and $28.72 \mathrm{wt} \%$, respectively, when compared to that of ZSM-5 (27.72 wt\%). As seen from Table 1, the hydrogen content in the pure $\mathrm{N}_{2}$ atmosphere over these catalysts was also increased, and the increase range was positively related to the increase of the aromatics yield. This indicates that $\mathrm{Zn}, \mathrm{Ag}$, and $\mathrm{Cu}$ can act as dehydro-metals, accelerate the dehydrogenation reaction, and promote the aromatization reaction, thus enhancing the aromatics yield. Other studies ${ }^{\mathbf{8 , 1 0}}$ also showed 


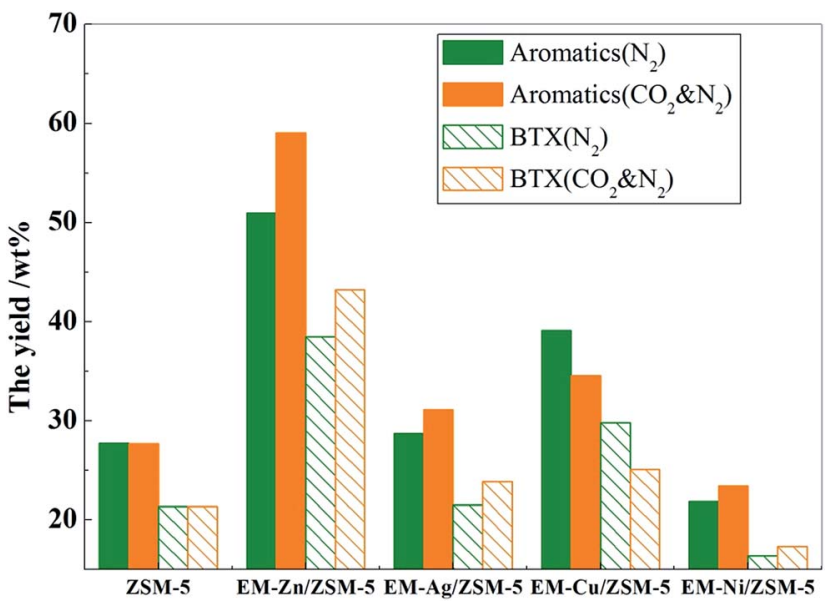

Fig. 1 Effect of reaction atmosphere on the yield of aromatics and BTX at ZSM-5 loaded with different but equimolar metal components $\left(\mathrm{WHSV}=1.0 \mathrm{~h}^{-1} ; P_{\text {methanol }}=50 \mathrm{kPa} ; n_{\mathrm{CO}_{2}}: n_{\mathrm{N}_{2}}=1: 1 ; T=475{ }^{\circ} \mathrm{C}\right.$; product samples were tested at $2.25 \mathrm{~h}$ ).

that $\mathrm{Zn}$ exhibits the best catalytic performance with methanol as a feedstock in $\mathrm{N}_{2}$ atmosphere. However, Ni has an effect different from the abovementioned elements. Compared with the unmodified ZSM-5 catalyst, the hydrogen content significantly increased, whereas the yield of aromatics significantly decreased. It could be observed that a large amount of methane was generated, leading to much coking, significant reduction in the aromatization activity, and decrease in the aromatics yield.

When $\mathrm{CO}_{2}$ was added to the reaction atmosphere, it was observed that there was almost no change in the yield of aromatics and BTX over ZSM-5; however, the yield of aromatics and BTX over the modified ZSM-5 significantly changed, which could be divided into two groups with opposite trends. The aromatic yield over the ZSM-5 catalysts doped with $\mathrm{Zn}, \mathrm{Ag}$, or Ni increased when compared to those in the absence of $\mathrm{CO}_{2}$, and among these, the aromatics yield over the EM-Zn/ZSM-5 system exhibited the largest increase of $8.1 \%$, followed by EM-Ag/ZSM-5 with an increase of $2.4 \%$. EM-Ni/ZSM-5 exhibited the smallest increase. Moreover, the contents of hydrogen, ethane, and propane were obviously reduced over these modified ZSM-5 catalysts. This indicates that the ZSM-5 catalysts modified by $\mathrm{Zn}, \mathrm{Ag}$, and Ni can catalyze the reaction of $\mathrm{CO}_{2}$ with $\mathrm{H}$, generated in the MTA process, thereby consuming hydrogen atoms and reducing the formation of alkanes, thus improving the yield of aromatics. In addition, the contents of benzene and toluene were almost unchanged, whereas the contents of $p$-xylene exhibited an obvious increase, which suggested that the promotion of $\mathrm{CO}_{2}$ mainly affected the formation of $p$-xylene. Note that the content of ethylene and propene exhibited a certain improvement over the $\mathrm{Ag}$ and $\mathrm{Ni}$-doped catalysts. The results of Ni-doped catalysts in the $\mathrm{CO}_{2}$ and $\mathrm{N}_{2}$ atmosphere exhibit a tendency similar to that previously reported in literature. ${ }^{20}$ However, for EM-Cu/ZSM-5, addition of $\mathrm{CO}_{2}$ reduced the yield of aromatics and the contents of hydrogen, ethane, and propane were slightly increased.

From the abovementioned results, it can be seen that the $\mathrm{Zn}$ modified catalyst had the best coupling effect on the aromatics yield of MTA in the presence of $\mathrm{CO}_{2}$, followed by $\mathrm{Ag}$ and Nimodified catalysts, whereas the Cu-modified catalyst exhibited reduction in the aromatics yield in the presence of $\mathrm{CO}_{2}$.

Table 1 MTA product distribution over ZSM-5 and loaded catalysts (WHSV $=1.0 \mathrm{~h}^{-1} ; P_{\text {methanol }}=50 \mathrm{kPa} ; n_{\mathrm{CO}_{2}}: n_{\mathrm{N}_{2}}=1: 1 ; T=475^{\circ} \mathrm{C} ;$ product samples were tested at $2.25 \mathrm{~h}$ )

\begin{tabular}{|c|c|c|c|c|c|c|c|c|c|c|}
\hline \multirow[b]{2}{*}{ Catalysts atmosphere } & \multicolumn{2}{|l|}{ ZSM-5 } & \multicolumn{2}{|c|}{ EM-Zn/ZSM-5 } & \multicolumn{2}{|c|}{ EM-Ag/ZSM-5 } & \multicolumn{2}{|c|}{ EM-Cu/ZSM-5 } & \multicolumn{2}{|c|}{ EM-Ni/ZSM-5 } \\
\hline & $\mathrm{N}_{2}$ & $\mathrm{CO}_{2} \& \mathrm{~N}_{2}$ & $\mathrm{~N}_{2}$ & $\mathrm{CO}_{2} \& \mathrm{~N}_{2}$ & $\mathrm{~N}_{2}$ & $\mathrm{CO}_{2} \& \mathrm{~N}_{2}$ & $\mathrm{~N}_{2}$ & $\mathrm{CO}_{2} \& \mathrm{~N}_{2}$ & $\mathrm{~N}_{2}$ & $\mathrm{CO}_{2} \& \mathrm{~N}_{2}$ \\
\hline \multicolumn{11}{|l|}{ Yield/wt\% } \\
\hline Hydrogen & 0.44 & 0.44 & 3.86 & 3.36 & 0.52 & 0.48 & 1.02 & 1.03 & 6.25 & 5.98 \\
\hline Methane & 6.05 & 6.07 & 5.71 & 5.38 & 7.81 & 7.64 & 6.47 & 6.90 & 22.80 & 20.39 \\
\hline Ethene & 3.91 & 3.92 & 6.74 & 6.87 & 3.03 & 3.70 & 3.72 & 3.52 & 2.60 & 3.06 \\
\hline Ethane & 4.15 & 4.14 & 2.36 & 1.89 & 4.58 & 4.16 & 2.72 & 3.29 & 12.26 & 11.20 \\
\hline Propene & 3.63 & 3.62 & 4.76 & 4.46 & 2.61 & 3.19 & 2.99 & 2.72 & 1.49 & 1.95 \\
\hline Propane & 30.79 & 30.71 & 6.27 & 4.85 & 27.74 & 26.23 & 17.31 & 21.18 & 13.59 & 14.11 \\
\hline Dimethyl ether & 0.00 & 0.00 & 0.00 & 0.00 & 0.00 & 0.00 & 0.00 & 0.00 & 0.00 & 0.00 \\
\hline Methanol & 0.00 & 0.00 & 0.00 & 0.00 & 0.00 & 0.00 & 0.00 & 0.00 & 0.00 & 0.00 \\
\hline $\mathrm{C}_{4}$ & 8.35 & 8.40 & 5.45 & 3.26 & 6.70 & 7.66 & 9.56 & 9.47 & 6.31 & 6.76 \\
\hline $\mathrm{C}_{5}$ & 0.57 & 0.58 & 1.55 & 0.79 & 0.52 & 0.72 & 1.56 & 1.29 & 0.85 & 0.83 \\
\hline $\mathrm{C}_{6}$ & 0.00 & 0.00 & 0.00 & 0.13 & 0.00 & 0.00 & 0.10 & 0.05 & 0.00 & 0.03 \\
\hline Benzene & 2.75 & 2.72 & 2.03 & 1.64 & 3.12 & 2.85 & 2.11 & 2.10 & 2.21 & 2.05 \\
\hline Toluene & 8.62 & 8.56 & 9.54 & 8.89 & 9.20 & 9.62 & 10.64 & 9.53 & 6.57 & 6.83 \\
\hline $\mathrm{C}_{7}$ & 0.00 & 0.00 & 0.00 & 0.00 & 0.00 & 0.00 & 0.00 & 0.00 & 0.00 & 0.00 \\
\hline $\mathrm{C}_{8}$ & 0.00 & 0.00 & 0.00 & 0.00 & 0.00 & 0.00 & 0.00 & 0.00 & 0.00 & 0.00 \\
\hline$m$-Xylene & 0.33 & 0.31 & 0.38 & 0.43 & 0.33 & 0.34 & 0.28 & 0.23 & 0.11 & 0.12 \\
\hline$p$-Xylene & 6.95 & 7.06 & 19.47 & 23.89 & 6.39 & 8.13 & 12.21 & 9.61 & 5.40 & 6.11 \\
\hline$o$-Xylene & 2.72 & 2.71 & 7.04 & 8.37 & 2.47 & 2.94 & 4.56 & 3.61 & 2.11 & 2.21 \\
\hline $\mathrm{C}_{9}$ & 1.66 & 1.67 & 1.29 & 1.24 & 2.24 & 1.72 & 2.23 & 1.77 & 2.05 & 1.95 \\
\hline Trimethylbenzene & 6.36 & 6.38 & 12.49 & 15.84 & 7.20 & 7.21 & 9.29 & 9.48 & 5.43 & 6.12 \\
\hline $\mathrm{C}_{10+}$ & 12.72 & 12.72 & 11.04 & 8.70 & 15.53 & 13.41 & 13.25 & 14.21 & 9.98 & 10.30 \\
\hline Conversion of $\mathrm{CO}_{2} / \%$ & - & 0.00 & - & 1.06 & - & 0.11 & - & 0.00 & - & 9.75 \\
\hline
\end{tabular}


Therefore, it is necessary to clarify the essential reason for differences in the coupling effects of the metals over ZSM-5 in the presence of $\mathrm{CO}_{2}$ on the aromatics yield of the MTA reaction.

\subsection{Physicochemical properties of the prepared catalysts}

Fig. 2 shows the XRD results of ZSM-5 and modified catalysts. All loaded catalysts exhibited characteristic diffraction peaks similar to ZSM-5. However, the diffraction peaks of metals were not detected. The XRD results suggest that the metal loading did not significantly affect the structure of zeolite, forming monolayer dispersion in ZSM-5. The specific surface areas and pore volumes of the catalysts listed in Table 2 slightly decreased, which might be caused by the metal loading on the internal and external surface and orifices of zeolites. Since the molar loading of metals was almost the same and all the loadings were small $(<3 \%)$, the pore volume and specific surface area of each catalyst did not change by more than $10 \%$, which hardly affected the shape-selectivity of the channel.

$\mathrm{CO}_{2}$ adsorption abilities for ZSM-5 and modified catalysts were studied by $\mathrm{CO}_{2}$-TPD and the results are shown in Fig. 3 . There was one peak at about $240{ }^{\circ} \mathrm{C}$ for ZSM- 5 that was ascribed to the desorption of weakly adsorbed $\mathrm{CO}_{2}$. However, the desorption peaks were shifted to a higher temperature upto about $375{ }^{\circ} \mathrm{C}$ after modification with $\mathrm{Ag}, \mathrm{Zn}, \mathrm{Cu}$, and Ni. This suggested that these loaded metals could strengthen the $\mathrm{CO}_{2}$ adsorption, which could be attributed to the interaction

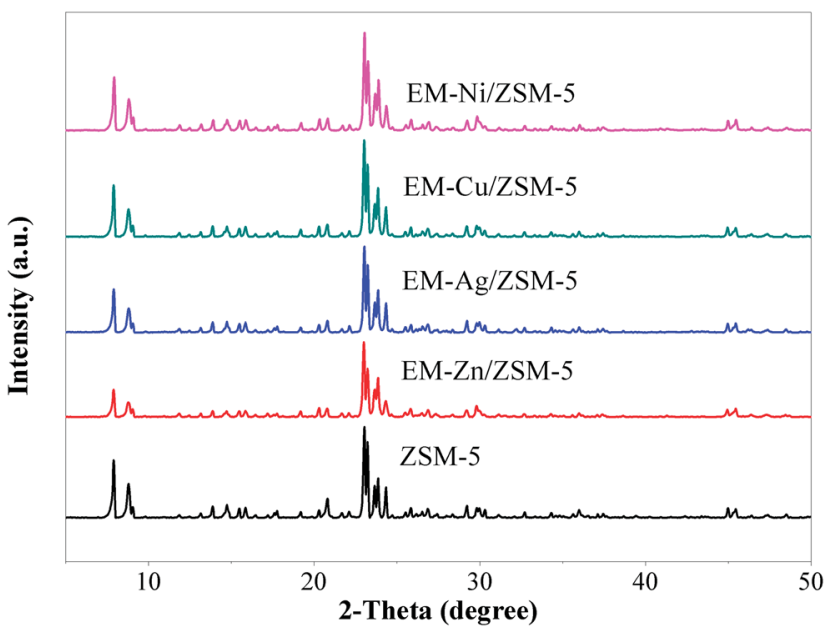

Fig. 2 XRD results of ZSM- 5 and loaded catalysts.

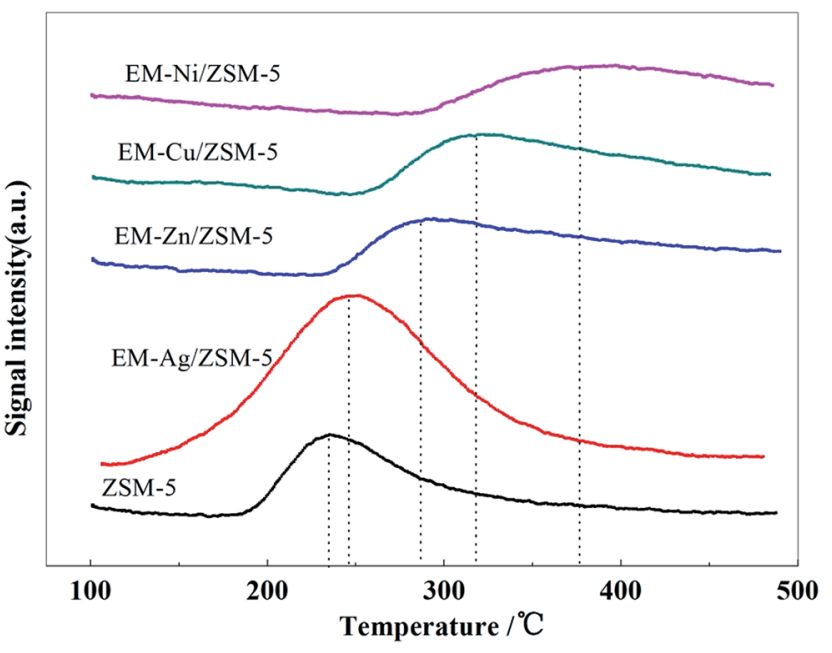

Fig. $3 \mathrm{CO}_{2}$-TPD results of ZSM-5 and loaded catalysts.

between metals and $\mathrm{CO}_{2}$ providing basic adsorbing sites. For EM-Ag/ZSM-5, the desorption peak was slightly shifted as compared to that of ZSM-5, whereas the area of the desorption peak was significantly increased, indicating that the loading of $\mathrm{Ag}$ only increased the number of weak adsorption active sites, whereas it did not enhance the overall adsorption strength. The weak adsorption of $\mathrm{CO}_{2}$ over EM-Ag/ZSM-5 limited its contact with the catalyst and thus weakened the consumption of hydrogen, which could increase the aromatics yield. The desorption peak of the catalysts modified by metals, including $\mathrm{Ni}, \mathrm{Cu}$, and $\mathrm{Zn}$, was shifted to a higher temperature, indicating strong interaction with $\mathrm{CO}_{2}$. Strong adsorption of $\mathrm{CO}_{2}$ contributes to its contact with the catalyst and occupation of the catalytic active sites. If the active sites can activate the adsorbed $\mathrm{CO}_{2}$ to effectively couple with hydrogen, the hydrogen in the system could be eliminated in situ, and then the yield of the aromatic hydrocarbons could be improved.

\subsection{The activation of $\mathrm{CO}_{2}$ to react with $\mathrm{H}_{2}$ over the prepared catalysts}

Ogonowski et al. ${ }^{17}$ reported that $\mathrm{CO}_{2}$ could react with $\mathrm{H}_{2}$ removed from alkenes and alkanes to form water and $\mathrm{CO}$ by a reversed water-gas-shift reaction. A new product of CO did appear over these modified ZSM-5 catalysts in the MTA reaction. $\mathrm{CO}_{2}$ conversion over these catalysts was calculated using $\mathrm{CO}$ produced through the reversed water-gas-shift reaction and

Table 2 Metal content, surface area, and pore volumes of ZSM-5 and loaded catalysts

\begin{tabular}{|c|c|c|c|c|c|}
\hline & ZSM-5 & EM-Zn/ZSM-5 & EM-Cu/ZSM-5 & EM-Ag/ZSM-5 & EM-Ni/ZSM-5 \\
\hline $\begin{array}{l}\text { Loaded molar weight, mmol } \mathrm{g}^{-1} \\
\text { (expected values) }\end{array}$ & & 0.229 & 0.229 & 0.229 & 0.229 \\
\hline $\begin{array}{l}\text { Loaded molar weight, mmol } \mathrm{g}^{-1} \\
\text { (observed values) }\end{array}$ & & 0.223 & 0.23 & 0.221 & 0.229 \\
\hline Surface area, $\mathrm{m}^{2} \mathrm{~g}^{-1}$ & 292.3 & 278.8 & 276.9 & 268.5 & 283.4 \\
\hline Pore volume, $\mathrm{mL} \mathrm{g}^{-1}$ & 0.064 & 0.057 & 0.057 & 0.054 & 0.059 \\
\hline Micropore & 0.131 & 0.129 & 0.129 & 0.126 & 0.130 \\
\hline
\end{tabular}


the results are listed in Table 1 . Note that the trend of $\mathrm{CO}_{2}$ conversion was different from the trend of aromatics yield on different metal-modified catalysts.

The reactions between $\mathrm{CO}_{2}$ and $\mathrm{H}_{2}$ (as raw materials) over these catalysts were investigated to explore their ability to activate $\mathrm{CO}_{2}$ to react with $\mathrm{H}_{2}$. Results demonstrated that $\mathrm{CO}_{2}$ could be activated to react with $\mathrm{H}_{2}$ and the conversion of $\mathrm{CO}_{2}$ remained stable during the course of the reaction over all the doped catalysts. It could be seen from Table 3 that not only $\mathrm{CO}$ but also a small amount of $\mathrm{CH}_{4}$ was produced, wherein $\mathrm{CO}$ made up the largest part of the products over the catalysts including EM-Zn/ZSM-5, EM-Cu/ZSM-5, and EM-Ag/ZSM-5, whereas $\mathrm{CH}_{4}$ was a relatively larger product over EM-Ni/ZSM5 . The results suggested that the reaction of generated $\mathrm{CO}$ with $\mathrm{H}_{2}$ might further undergo eqn (2) when $\mathrm{CO}_{2}$ is reacted with $\mathrm{H}_{2}$ via the reversed water-gas-shift reaction, as shown in eqn (1). For example, when $\mathrm{CO}_{2}$ was added to the MTA reaction mixture, both reactions (not just the reversed water-gas-shift reaction) occurred to rapidly consume hydrogen from the intermediates, as reported by $\mathrm{Li}$ et $\mathrm{al.}^{\mathbf{2 0}}$ Moreover, hydrogen was mainly consumed via eqn (2) over EM-Ni/ZSM-5, whereas it was mostly consumed via eqn (1) over the other three catalysts.

$$
\begin{aligned}
& \mathrm{CO}_{2}+\mathrm{H}_{2} \rightarrow \mathrm{CO}+\mathrm{H}_{2} \mathrm{O} \\
& \mathrm{CO}+3 \mathrm{H}_{2} \rightarrow \mathrm{H}_{2} \mathrm{O}+\mathrm{CH}_{4}
\end{aligned}
$$

Fig. 4 shows the $\mathrm{CO}_{2}$ conversion for the reaction of $\mathrm{CO}_{2}$ with $\mathrm{H}_{2}$ and the increase of aromatics yield in the MTA reaction in the presence of $\mathrm{CO}_{2}$ over these modified ZSM-5 catalysts at the same TOS (TOS $=2.25 \mathrm{~h}$ ). It can be seen that $\mathrm{CO}_{2}$ conversion for the reaction of $\mathrm{CO}_{2}$ with $\mathrm{H}_{2}$ gradually increased over the catalysts in the order of $\mathrm{Cu}>\mathrm{Ag}>\mathrm{Zn}>$ Ni-modified catalysts, indicating that the catalytic abilities for activating $\mathrm{CO}_{2}$ to react with $\mathrm{H}_{2}$ increase in turn. The aromatics yield increased in the same order except for the Ni-modified catalyst, and the value increased from $-4.5 \%$ over EM-Cu/ZSM- 5 to 8.1\% over EM-Zn/ZSM-5. The conversion of $\mathrm{CO}_{2}$ over EM-Ni/ ZSM-5 was the highest, whereas the increase in aromatics yield was only $1.61 \%$.

Based on the abovementioned results, it can be concluded that the increase of aromatics yield of MTA over the modified catalysts in $\mathrm{CO}_{2}$ atmosphere is determined by the interaction of three essential catalytic factors: the ability of the catalyst to adsorb $\mathrm{CO}_{2}$, the ability of the metal over the catalyst to catalyze

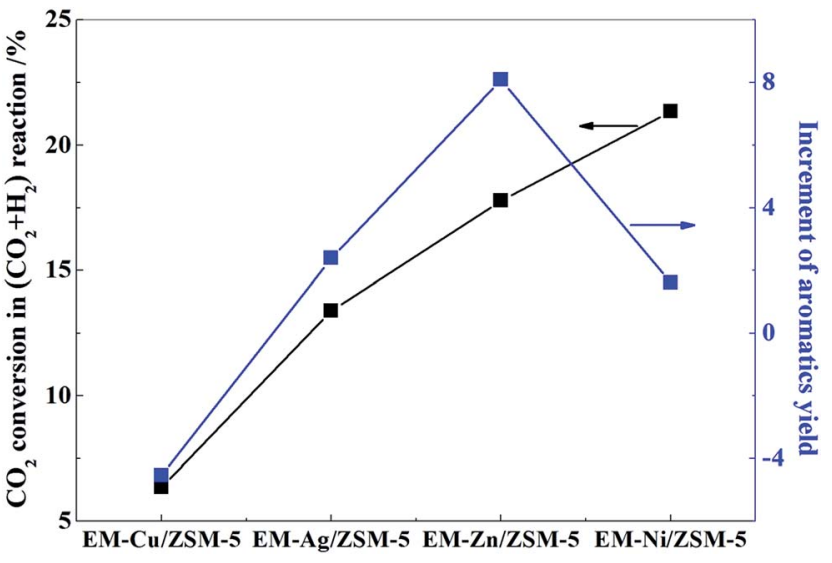

Fig. 4 Changes in the aromatics yield in the MTA reaction in presence of $\mathrm{CO}_{2}$ and $\mathrm{CO}_{2}$ conversion in the $\mathrm{CO}_{2}+\mathrm{H}_{2}$ reaction $\left(n_{\mathrm{CO}_{2}}: n_{\mathrm{N}_{2}}=1: 1\right.$; $T=475{ }^{\circ} \mathrm{C}$; the ratio of $\mathrm{H}_{2} / \mathrm{N}_{2}$ is approximately equal to $2.0 ;$ TOS $=$ $2.25 \mathrm{~h})$

the reaction of $\mathrm{CO}_{2}$ with $\mathrm{H}_{2}$, and the dehydroaromatization ability of the catalyst. If the metal over the catalyst is capable of efficiently activating $\mathrm{CO}_{2}$ and catalyzing the reaction of $\mathrm{CO}_{2}$ with $\mathrm{H}_{2}$ to form $\mathrm{CO}$ and $\mathrm{CH}_{4}$ via eqn (1) and (2), the metal can effectively displace the olefin as the temporary hydrogen receptors to rapidly remove the hydrogen produced during the MTA, reducing the formation of alkanes and thereby increasing the yield of aromatics. If the catalyst cannot effectively activate $\mathrm{CO}_{2}$ to react with $\mathrm{H}_{2}$, whereas has a strong adsorption capacity for $\mathrm{CO}_{2}, \mathrm{CO}_{2}$ cannot be timely consumed and will occupy the active sites of the catalyst to inhibit the MTA reaction. When the dehydroaromatization ability of the catalyst itself is insufficient, adding $\mathrm{CO}_{2}$ hardly promotes the aromatization reaction of methanol even if the ability of the catalyst to adsorb $\mathrm{CO}_{2}$ and to catalyze the reaction of $\mathrm{CO}_{2}$ with $\mathrm{H}_{2}$ is excellent.

For the EM-Cu/ZSM-5 catalyst, it is difficult to promote the dehydroaromatization due to its poor ability to catalyze the reaction of $\mathrm{CO}_{2}$ with $\mathrm{H}_{2}$ (Fig. 4); however, there is a strong absorption for $\mathrm{CO}_{2}$ (Fig. 3). On adding $\mathrm{CO}_{2}$ to the reaction atmosphere, it is easy for $\mathrm{CO}_{2}$ to occupy a large number of active sites, which not only hardly accelerates the elimination of hydrogen from the intermediate, but also weakens the aromatization reaction, and then decreases the yield of aromatics.

For EM-Ag/ZSM-5 and EM-Zn/ZSM-5 catalysts, the latter has a better ability to adsorb $\mathrm{CO}_{2}$ (Fig. 3) and to catalyze the reaction of $\mathrm{CO}_{2}$ with $\mathrm{H}_{2}$ (Fig. 4), as well as better dehydroaromatization ability

Table 3 Product distributions of $\mathrm{CO}_{2}+\mathrm{H}_{2}$ at ZSM-5 loaded with different but equimolar metal components $\left(n_{\mathrm{CO}_{2}}: n_{\mathrm{N}_{2}}=1: 1 ; T=475{ }^{\circ} \mathrm{C} ;\right.$ ratio of $\mathrm{H}_{2} / \mathrm{N}_{2}$ is approximately equal to 2.0; product samples were tested at $2.25 \mathrm{~h}$ )

Composition \&

volume content $/ \%$

$\mathrm{H}_{2}$

$\mathrm{N}_{2}$

$\mathrm{CO}$

$\mathrm{CO}_{2}$

$\mathrm{CH}_{4}$
EM-Zn/ZSM-5

49.94

23.76

4.59

21.57

0.14
EM-Cu/ZSM-5

50.67

21.99

1.67

25.61

0.06
EM-Ag/ZSM-5

49.91

22.27

3.58

24.10

0.14
EM-Ni/ZSM-5

22.76

3.34 
(Fig. 1 and Table 1). Consequently, the increase in aromatics yields over EM-Zn/ZSM-5 was larger than that over EM-Ag/ZSM-5 when adding $\mathrm{CO}_{2}$ into the MTA reaction atmosphere. In addition, due to the weaker dehydroaromatization ability of EM-Ag/ ZSM-5, the olefin intermediates obtained from the dehydrogenation cannot fully undergo the aromatization reaction, resulting in the higher content of ethane and propane and lower aromatics yield over EM-Ag/ZSM-5 than those over EM-Zn/ZSM-5 in the presence of $\mathrm{CO}_{2}$. The EM-Ni/ZSM-5 catalyst has a strong ability to adsorb and activate $\mathrm{CO}_{2}$ (Fig. 3); however, its coking deactivation suppresses its ability to catalyze fundamental carbocation reactions, especially the aromatization reaction of the intermediates. As a consequence, although the EM-Ni/ZSM- 5 catalyst can catalyze the reaction between $\mathrm{CO}_{2}$ and $\mathrm{H}_{2}$ to reduce the content of alkanes and increase the content of olefins, it cannot greatly improve the aromatics yield when $\mathrm{CO}_{2}$ is added into the MTA atmosphere.

\subsection{Methanol aromatization over catalysts modified with different contents of $\mathrm{Zn}$ in the presence or absence of $\mathrm{CO}_{2}$}

The XRD results (Fig. 5) indicate that the structure of ZSM-5 did not change when ZSM-5 was impregnated with different contents of $\mathrm{Zn}$, even up to $2.0 \mathrm{wt} \%$. As shown in Fig. 6, the introduction of zinc species on ZSM- 5 had a certain influence on the distribution of acid sites and acidity. With the increase of $\mathrm{Zn}$ content, the amount of weak acid sites increased and the amount of strong acid sites decreased, which may be due to the fact that some acid sites were covered and $\mathrm{Zn}-\mathrm{L}$ weak acid sites were generated. ${ }^{22}$ Fig. 7 shows the $\mathrm{CO}_{2}$-TPD results of the ZSM-5 modified with different contents of $\mathrm{Zn}$. When $\mathrm{Zn}$ content was increased to $1.0 \mathrm{wt} \%$, desorption peak temperature remained at about $240{ }^{\circ} \mathrm{C}$, whereas the area of the desorption peak significantly increased. The desorption peak was shifted to a higher temperature when the $\mathrm{Zn}$ content continued to increase. These changes indicate that the ability of the catalyst to adsorb $\mathrm{CO}_{2}$ increased with the increasing $\mathrm{Zn}$ content.

Fig. 8 shows the conversion of $\mathrm{CO}_{2}$ in the reaction of $\mathrm{CO}_{2}$ with $\mathrm{H}_{2}$ catalyzed by the ZSM-5 modified with different contents

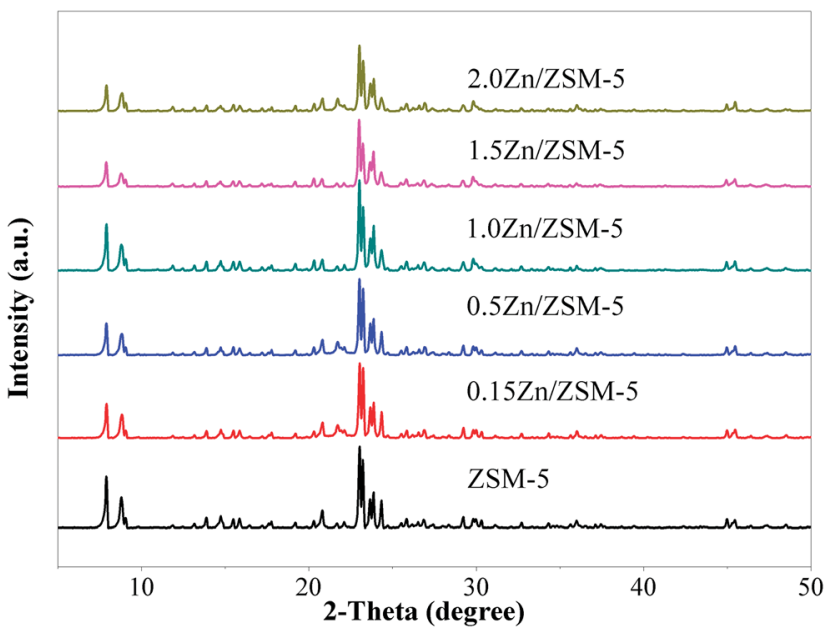

Fig. 5 XRD results of ZSM-5 with different contents of $Z n$.

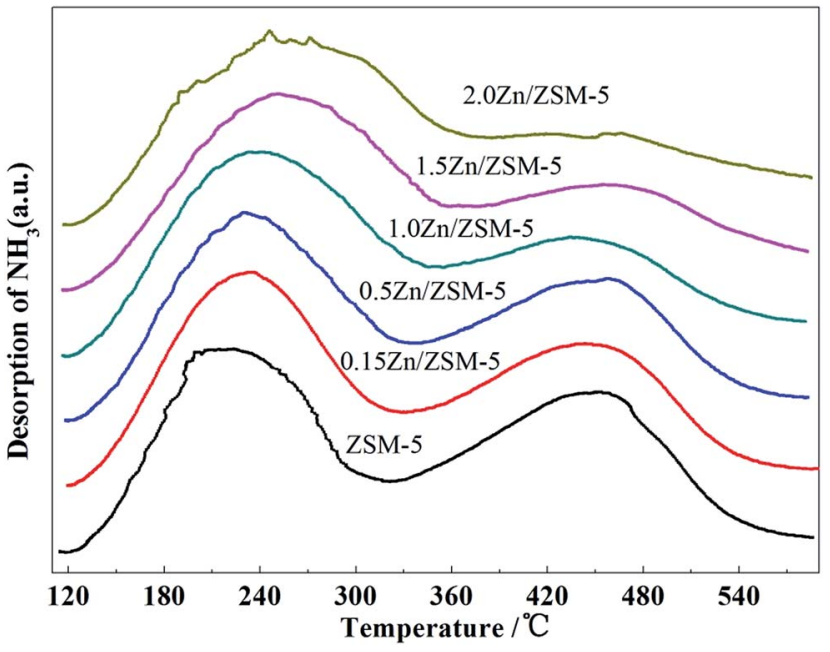

Fig. $6 \mathrm{NH}_{3}-\mathrm{TPD}$ results of $\mathrm{ZSM}-5$ with different contents of $\mathrm{Zn}$.

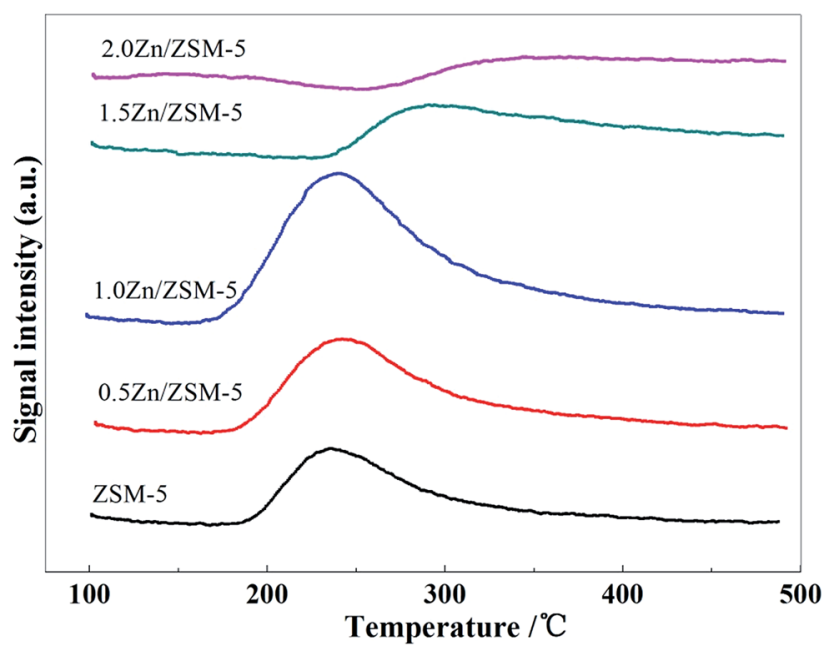

Fig. $7 \mathrm{CO}_{2}$-TPD results of ZSM-5 with different contents of $\mathrm{Zn}$.

of $\mathrm{Zn}$. It was observed that the conversion of $\mathrm{CO}_{2}$ remained very low up to a $\mathrm{Zn}$ content of $0.5 \mathrm{wt} \%$, and then rapidly increased with the increase in the $\mathrm{Zn}$ content upto $1.5 \mathrm{wt} \%$. The conversion of $\mathrm{CO}_{2}$ slightly increased when the content of $\mathrm{Zn}$ increased from $1.5 \mathrm{wt} \%$ to $2.0 \mathrm{wt} \%$. This suggests that the ability of the metal over the catalyst to catalyze the reaction of $\mathrm{CO}_{2}$ with $\mathrm{H}_{2}$ increased with the increasing $\mathrm{Zn}$ content.

The results of methanol aromatization over the catalysts loaded with different contents of $\mathrm{Zn}$ in the presence and absence of $\mathrm{CO}_{2}$ are shown in Fig. 9. The changes in the aromatics yield for the MTA reaction in the presence of $\mathrm{CO}_{2}$ is shown in Fig. 8. As can be seen, aromatics yield increased with the increasing $\mathrm{Zn}$ content in the $\mathrm{N}_{2}$ atmosphere upto a maximum $\mathrm{Zn}$ content of $1.0 \mathrm{wt} \%$, and then gradually decreased. After the addition of $\mathrm{CO}_{2}$, the aromatics yield slightly reduced than that in a $\mathrm{N}_{2}$ atmosphere when the content of $\mathrm{Zn}$ was not greater than $0.5 \mathrm{wt} \%$. Then, the increase of the aromatics yield in the MTA reaction in the presence of $\mathrm{CO}_{2}$ was positive with the increasing $\mathrm{Zn}$ content and reached 


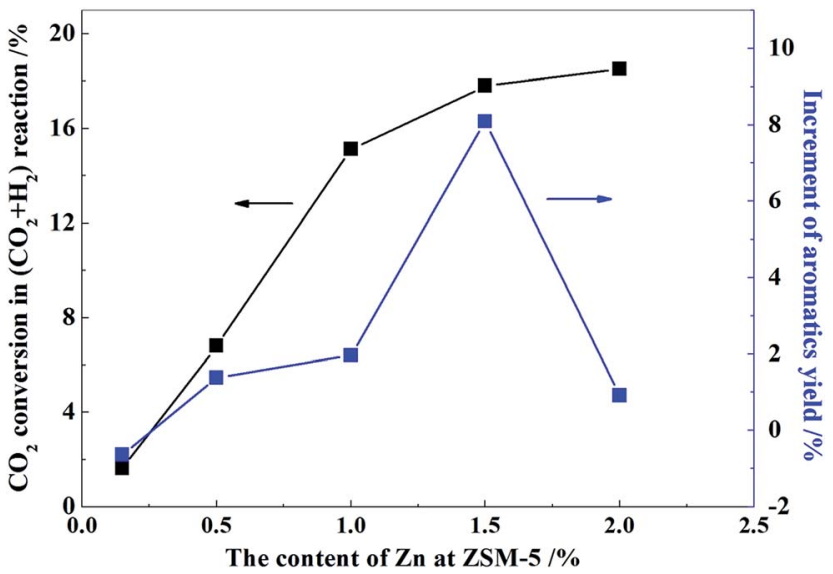

Fig. 8 Changes in the aromatics yield in the MTA reaction in the presence of $\mathrm{CO}_{2}$ and $\mathrm{CO}_{2}$ conversion in the $\mathrm{CO}_{2}+\mathrm{H}_{2}$ reaction $\left(n_{\mathrm{CO}_{2}}: n_{\mathrm{N}_{2}}=1: 1 ; T\right.$ $=475^{\circ} \mathrm{C}$; the ratio of $\mathrm{H}_{2} / \mathrm{N}_{2}$ is approximately equal to 2.0 ; $\mathrm{TOS}^{2}=2.25 \mathrm{~h}$ ).

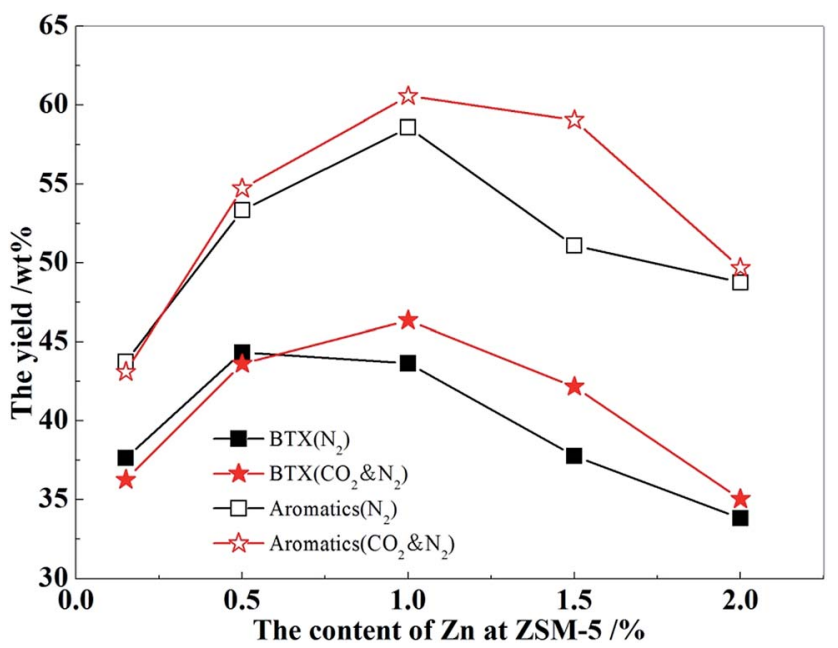

Fig. 9 The effect of the content of Zn on the selectivity of aromatics and BTX in the presence (star symbols) or absence (square symbols) of $\mathrm{CO}_{2}\left(\mathrm{WHSV}=1.0 \mathrm{~h}^{-1} ; P_{\text {methanol }}=50 \mathrm{kPa} ; n_{\mathrm{CO}_{2}}: n_{\mathrm{N}_{2}}=1: 1 ; T=475^{\circ} \mathrm{C}\right.$; product samples were tested at $2.25 \mathrm{~h}$ ).

a maximum of $8.1 \%$ at a $\mathrm{Zn}$ content of $1.5 \mathrm{wt} \%$. When $\mathrm{Zn}$ content was low, a large number of strong acid sites of the catalysts (Fig. 6) promoted the hydrogen transfer reaction of biomolecules, resulting in a large amount of alkanes, a poor aromatics yield, and little hydrogen generation. Moreover, the small number of metal centers over the catalysts had an insufficient ability to catalyze the reaction of $\mathrm{CO}_{2}$ with $\mathrm{H}_{2}$ (Fig. 8). Therefore, adding $\mathrm{CO}_{2}$ did not increase the yield of aromatic hydrocarbons, whereas weakened the dehydroaromatization ability of the catalyst due to the competitive adsorption of $\mathrm{CO}_{2}$, accompanied by the increase of alkanes and hydrogen (Fig. 10). As the $\mathrm{Zn}$ content increased from 1.0 to $1.5 \mathrm{wt} \%$, the adsorption and activation capability of the catalysts for $\mathrm{CO}_{2}$ were significantly boosted (Fig. 7 and 8), such that the elimination of hydrogen was accelerated and the balance of dehydrogenation and hydrogenation was further broken. Hence, the change in aromatics yield was positive and was significantly improved (Fig. 8). At the same time, the amount of alkanes and hydrogen was decreased (Fig. 10) on adding $\mathrm{CO}_{2}$ into the MTA atmosphere.

When the content of $\mathrm{Zn}$ was increased to $2.0 \mathrm{wt} \%$, a large number of strong acid sites of ZSM-5 were destroyed, which affected the reaction of the carbocation at the acid site, and the aromatics yield rapidly decreased. Thus, the catalyst could not effectively catalyze the aromatization reaction of olefin intermediates in spite of the strong ability of the catalyst to adsorb $\mathrm{CO}_{2}$ and catalyze the reaction of $\mathrm{CO}_{2}$ with $\mathrm{H}_{2}$. Therefore, in the presence of $\mathrm{CO}_{2}$, the yield of aromatics could not be significantly improved compared to the nitrogen atmosphere, and the content of alkanes and hydrogen could not decrease further either. Thus, there was a flat trend, as shown in Fig. 10.

\section{Conclusions}

ZSM-5 catalysts modified by $\mathrm{Zn}, \mathrm{Ni}, \mathrm{Ag}$, and $\mathrm{Cu}$ were investigated in the presence or absence of $\mathrm{CO}_{2}$ for methanol to aromatics in a fixed-bed reactor. It was demonstrated that catalysts doped with $\mathrm{Zn}, \mathrm{Ni}$, and $\mathrm{Ag}$ were capable of increasing the total aromatics yield via promoting the rapid elimination of hydrogen in the system. This was achieved by catalyzing the reaction of $\mathrm{CO}_{2}$ with hydrogen to generate $\mathrm{CO}$ and $\mathrm{CH}_{4}$ when adding $\mathrm{CO}_{2}$ into the MTA reaction atmosphere. The EM-Zn/ ZSM-5 showed 59.05 wt\% aromatics yield, which was an increase of $8.1 \%$ compared to that in $\mathrm{N}_{2}$ atmosphere. However, $\mathrm{EM}-\mathrm{Cu} / \mathrm{ZSM}-5$ was found to reduce the aromatics yield as
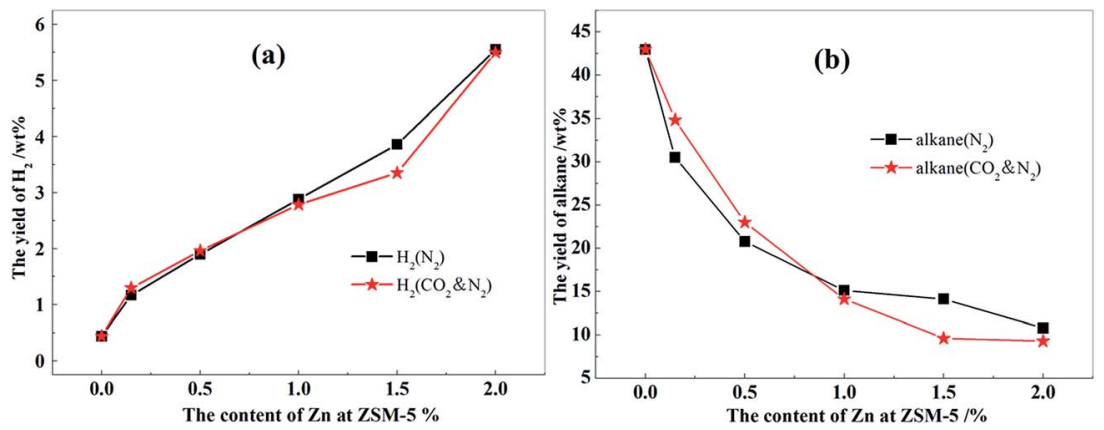

Fig. 10 Concentration of $\mathrm{H}_{2}$ and alkanes in the presence (star symbols) or absence (square symbols) of $\mathrm{CO}_{2}$ at $\mathrm{ZSM}^{-5}$ with different contents of $\mathrm{Zn}$ in MTA (WHSV $=1.0 \mathrm{~h}^{-1} ; P_{\text {methanol }}=50 \mathrm{kPa} ; n_{\mathrm{CO}_{2}}: n_{\mathrm{N}_{2}}=1: 1 ; T=475^{\circ} \mathrm{C}$; product samples were tested at $2.25 \mathrm{~h}$ ). 
a result of the fact that the active sites were occupied by a large number of $\mathrm{CO}_{2}$ molecules.

Moreover, methanol aromatization over the catalysts modified with different contents of $\mathrm{Zn}$ in the presence or absence of $\mathrm{CO}_{2}$ was investigated. It was found that the aromatics yield increased with the increasing $\mathrm{Zn}$ content in the $\mathrm{N}_{2}$ atmosphere, up to a maximum $\mathrm{Zn}$ content of $1.0 \mathrm{wt} \%$, and then gradually decreased. With the increase of the $\mathrm{Zn}$ content, the change of the aromatics yield in the MTA reaction in the presence of $\mathrm{CO}_{2}$ was negative, then turned positive, and finally reached a maximum of $8.1 \%$ at a $\mathrm{Zn}$ content of $1.5 \mathrm{wt} \%$.

It was further found that the increase of the aromatics yield of the MTA reaction over the modified catalysts in a $\mathrm{CO}_{2}$ atmosphere is determined by the interaction of three essential catalytic factors: the ability of the catalyst to adsorb $\mathrm{CO}_{2}$, the ability of the metal over the catalyst to catalyze the reaction of $\mathrm{CO}_{2}$ with $\mathrm{H}_{2}$, and the dehydroaromatization ability of the catalyst. If the metal over the catalyst is capable of efficiently activating $\mathrm{CO}_{2}$ and catalyzing the reaction of $\mathrm{CO}_{2}$ with $\mathrm{H}_{2}$, the metal can effectively displace the olefin as a temporary hydrogen receptor to rapidly remove hydrogen produced during the MTA, reducing the formation of alkanes, thereby increasing the yield of aromatics. If the catalyst cannot effectively activate $\mathrm{CO}_{2}$ to react with $\mathrm{H}_{2}$, whereas has a strong adsorption capacity for $\mathrm{CO}_{2}, \mathrm{CO}_{2}$ cannot be timely consumed and will occupy the active sites of the catalyst to inhibit the MTA reaction. When the dehydroaromatization ability of the catalyst itself is insufficient, addition of $\mathrm{CO}_{2}$ hardly promotes the aromatization reaction of methanol even if the ability of the catalyst to adsorb $\mathrm{CO}_{2}$ and catalyze the reaction of $\mathrm{CO}_{2}$ with $\mathrm{H}_{2}$ is excellent.

It has also been demonstrated that there are two reactions that will generate $\mathrm{CO}$ and $\mathrm{CH}_{4}$, not just the reversed water-gas-shift reaction, when $\mathrm{CO}_{2}$ is added into the MTA reaction atmosphere.

\section{Acknowledgements}

The authors gratefully acknowledge the support and encouragement of the National Natural Science Foundation of China (21176208), National Basic Research Program of China (2012CB720500), and Fundamental Research Funds for the Central Universities (2011QNA4032).

\section{References}

1 Y. Q. Zhang, Technology \& Economics in Petrochemicals, 2013, vol. 29, pp. 3-6.
2 Y. C. Zhang, H. X. Wang, X. W. Zhang and K. J. Li, Chem. Ind. Eng. Prog., 2016, 35, 801-805.

3 BP Statistical Review of World Energy, 2015.

4 T. Wang, X. P. Tang, X. F. Huang, W. Z. Qian, Y. Cui, X. Y. Hui, W. Yang and F. Wei, Catal. Today, 2014, 233, 8-13.

5 Z. H. Zeng, Shape selective catalysis, China Petrochemical Press, Beijing, 1994.

6 D. L. Zeng, J. Yang, J. Q. Wang, J. Xu, Y. X. Yang, C. H. Ye and F. Deng, Microporous Mesoporous Mater., 2007, 98, 214-219.

7 T. Tian, Z. W. Qian, X. P. Tang, H. Song and F. Wei, Acta Phys.-Chim. Sin., 2010, 26, 3305-3309.

8 J. A. Lopez-Sanchez, M. Conte, P. Landon, J. K. Bartley, S. H. Taylor and A. F. Carley, Catal. Lett., 2012, 142, 10491056.

9 Y. M. Ni, A. M. Sun, X. L. Wu, G. L. Hai, J. L. Hu, T. Li and G. X. Li, Microporous Mesoporous Mater., 2011, 143, 435-442.

10 M. Conte, J. A. Lopez-Sanchez, Q. He, D. J. Morgan, Y. Ryabenkova, J. K. Bartley, A. F. Carley, S. H. Taylor, C. J. Kiely, K. Khalid and G. J. Hutchings, Catal. Sci. Technol., 2012, 2, 105-112.

11 J. G. Zhang, W. Z. Qian, C. Y. Kong and F. Wei, ACS Catal., 2015, 5, 2982-2988.

12 Y. Bi, Y. L. Wang, X. Chen, Z. X. Yu and L. Xu, Chin. J. Catal., 2014, 35, 1740-1751.

13 J. S. Chang, V. P. Vislovskiy, M. S. Park, D. Y. Hong, J. S. Yoo and S. E. Park, Green Chem., 2003, 5, 587-590.

14 N. R. Shiju, M. Anilkumar, S. P. Mirajkar and C. V. Satyanarayana, J. Catal., 2005, 230, 484-492.

15 C. R. Adams and T. J. Jennings, J. Catal., 1970, 17, 157-177.

16 G. S. Sun, Q. Z. Huang, H. Q. Li, H. T. Liu, Z. Zhang, X. R. Wang, Q. P. Wang and J. S. Wang, Chin. J. Catal., 2011, 32, 1424-1429.

17 J. Ogonowski and E. Skrzynska, Catal. Commun., 2009, 11, 132-136.

18 G. S. Sun, Q. Z. Huang, H. Q. Li, H. T. Liu, Z. Zhang, X. R. Wang, Q. P. Wang and J. S. Wang, Chin. J. Catal., 2011, 32, 1424-1429.

19 J. F. Ding, Z. F. Qin, X. K. Li, G. F. Wang and J. G. Wang, J. Mol. Catal. A: Chem., 2010, 315, 221-225.

20 J. H. Li, C. Hu, K. Tong, H. Xiang, Z. R. Zhu and Z. H. Hu, RSC Adv., 2014, 4, 44377-44385.

21 P. Michorczyk and J. Ogonowski, React. Kinet. Catal. Lett., 2003, 78, 41-47.

22 J. Y. Wang, W. H. Li and J. X. Hu, J. Fuel Chem. Technol., 2009, 37, 607-612. 